\title{
Evaluation and characterization of groundwater of the Maastrichtian Lafia formation, Central Benue trough, Nigeria
}

\author{
Nuhu Degree Umar*, Ogbonnaya Igwe and Ibrahim Giza Idris \\ Department of Geology, University of Nigeria, Nsukka, Nigeria. \\ *Corresponding author.e-mail: degree.umar.pg76650@unn.edu.ng
}

MS received 30 January 2018; revised 25 October 2018; accepted 16 April 2019; published online 17 June 2019

Hydrochemical assessment of groundwater in the Lafia formation, Central Benue trough, Nigeria was carried out with the aim of determining its quality for domestic and irrigation purposes. Thirty groundwater samples from boreholes and hand-dug wells were analyzed using atomic spectrometry and titrimetric methods. The water quality index (WQI) was evaluated from physicochemical parameters and used in assessing the groundwater quality for drinking, while the electrical conductivity (EC), percentage sodium (\% Na), sodium absorption ratio (SAR) and magnesium hardness $(\mathrm{MH})$ were evaluated to assess its suitability for irrigation. The physico-chemical parameters in order of dominance are $\mathrm{HCO}_{3}^{-}>\mathrm{NO}_{3}^{-}>$ Cl- $>\mathrm{PO}_{3}^{-}>\mathrm{SO}_{4}^{2-}$ for the anions and $\mathrm{Fe}^{3+}>\mathrm{Na}^{+}>\mathrm{Ca}^{2+}>\mathrm{Mg}^{2+}>\mathrm{Pb}^{2+}>\mathrm{K}^{+}$for the cations. The $\mathrm{pH}$ indicates acidic to weakly alkaline water (5.1-7.3); EC ranges from 110 to $1396 \mu \mathrm{S} / \mathrm{cm}$, while the total dissolved solids range between 136.9 and $3.4 \mathrm{mg} / \mathrm{l}$, based on which it is classified as freshwater. WQI showed that only $40 \%$ of the groundwater samples are suitable while $60 \%$ are unsuitable for drinking and will therefore require treatment. Three water facies: $\mathrm{Ca}^{2+}+\mathrm{Mg}^{2+}, \mathrm{Ca}^{2+}+\mathrm{Na}^{+}+\mathrm{K}^{+}$and $\mathrm{HCO}_{3}^{-}$ characterized the area indicating the groundwater-quality situation. Based on EC classification, $33.33 \%$ of the water samples are considered excellent, $60 \%$ as good, $6.67 \%$ as permissible while on the basis of $\% \mathrm{Na}$, only $13.34 \%$ are unsuitable for irrigation. SAR of 96.67 and $3.33 \%$ of the groundwater samples indicate excellent and doubtful waters, respectively. $93.4 \%$ of groundwater samples has $\mathrm{MH}<50$ and are considered suitable for irrigation.

Keywords. Lafia; groundwater; geologic formation; water quality index; water facies; irrigation.

\section{Introduction}

Groundwater is an essential element for human existence on earth. The hydrochemistry of groundwater is very important with regard to drinking, irrigation and industrial water supplies, as the presence of certain chemical constituents makes the groundwater unfit for industrial and agricultural use (Michael 1990). Around the world, the availability of high-quality groundwater for human consumption is on the decline (Bouderbala et al. 2016). The quality of groundwater can significantly be impacted by land usage, geology and anthropogenic activities (Bocanegra et al. 2013).

Groundwater chemistry generally shows a direct relationship with its quality and determines it suitability or unsuitability for domestic, industrial and agricultural purposes. For many years, due to the inadequate supply of water from the municipal water supply, hand-dug wells and boreholes 
have been the major sources of water supply in Lafia and environs. However, information about the physico-chemical characteristics of the groundwater with respect to drinking and agricultural purposes has not been prioritized, as water from these boreholes is put to use without a quality test. The determination of groundwater quality for human consumption is important for the wellbeing of the increasing population (Ishaku 2011). It is therefore pertinent to establish those quality criteria for healthy living and improved food production, considering the growing population and increased agricultural activities in the study area. These qualities are dependent on the quality of recharged water, atmospheric precipitation, inland surface water and subsurface geochemical processes (Vasanthavigar et al. 2010).

Various researchers (Offodile 1976a, 1983, 2002; Aku 1983; Achohwora 1986) who have worked on the study area focused on its geology, hydrogeology, groundwater occurrence and aquifer's yield, while little is known about its hydrochemistry and suitability for drinking and irrigation. Kumar (2013) studied groundwater chemistry and identified natural processes as controlling factors of the hydrochemistry, while Ishaku et al. (2012) identified anthropogenic contaminations, natural mineralisation and cation exchange as factors controlling the hydrochemistry. Groundwater quality for drinking and agricultural or other purposes has been studied (Onwuka et al. 2004, 2013; Ehirim et al. 2009; Prasanna et al. 2011; Ishaku et al. 2012; Rao et al. 2013; Omonona et al. 2014; Das and Nag 2015; Akpah et al. 2017).

Water quality index (WQI) is an important technique for demarcating groundwater quality and its suitability for drinking (Tiwari and Mishra 1985). Ishaku et al. (2012) and Omonona et al. (2014) used the WQI to classify groundwater for drinking. Das and Nag (2015) calculated water indices such as the sodium absorption ratio (SAR), permeability index (PI), residual sodium carbonate (RSC) and Kelley ratio (KR) to identify the irrigational suitability of groundwater.

The present investigation focuses on the evaluation and characterization of groundwater chemistry, its quality for drinking and agricultural purposes. Water supply for drinking and irrigation in this region is sourced through groundwater as the annual average rainfall range is between 1000 and $1500 \mathrm{~mm}$ (Binbol 2006). There are no major polluting industries in the study area.
WQI, Piper trilinear diagram and total hardness were used to classify water for drinking while electrical conductivity (EC), percentage sodium (\%Na) according to Raghunath (1987), Sadashivaiah et al. (2008) and Hagras (2013), SAR according to Richard (1954) and Todd and Mays (2005) and magnesium hardness (MH) according to Szabolcs and Darab (1964) was evaluated to classify water for irrigation.

\subsection{Study area description}

Lafia, the capital of the Nasarawa state in north central Nigeria, and its environs lie between latitude $8^{\circ} 18^{\prime}-8^{\circ} 42^{\prime} \mathrm{N}$ and longitude $8^{\circ} 18^{\prime}-8^{\circ} 48^{\prime} \mathrm{E}$ (figure 1). Two major distinct seasons (wet and dry) characterise the area; the wet season lasts from March to October, while the dry season lasts from November to February. Rainfall between January and February is a rare occurrence. The annual average rainfall ranges between 1000 and $1500 \mathrm{~mm}$ while the mean annual humidity is $70 \%$ and the relative humidity is $60-80 \%$ (Binbol 2006). The annual average temperature is $28.5^{\circ} \mathrm{C}$ with an annual average sunshine hour of 6.7 per day. A high temperature of $33-36^{\circ} \mathrm{C}$ is experienced in the area during the dry season.

The study area is drained majorly by River Amba and is characterized by the Guinean savannah vegetation.

The original vegetation has been tampered with due to human activities such as farming, bush burning and grazing, which has given rise to a secondary forest (Achohwora 1986).

\subsection{Geology of the study area}

The study area is underlain by the Lafia formation also called the 'Lafia sandstone' by Cratchley and Jones (1965). It is the youngest formation in the Central Benue trough, Nigeria (Zaborski 1998). It was deposited under continental (fluviatile) condition in the Maastrichtian and lies uncomformably on the Awgu formation which was deposited during the Late Turonian transgression, early Coniacian and terminated in the early Santonian. This deposition marks the end of marine sedimentation in this part of the Benue trough. It consists of bluishgrey to dark black carbonaceous shales, calcareous shale, shaley limestone, limestone, sandstones, siltstones and coal seams. The Lafia formation is lithologically characterised by ferruginised sandstones, red loose sands, flaggy mudstones, clays 


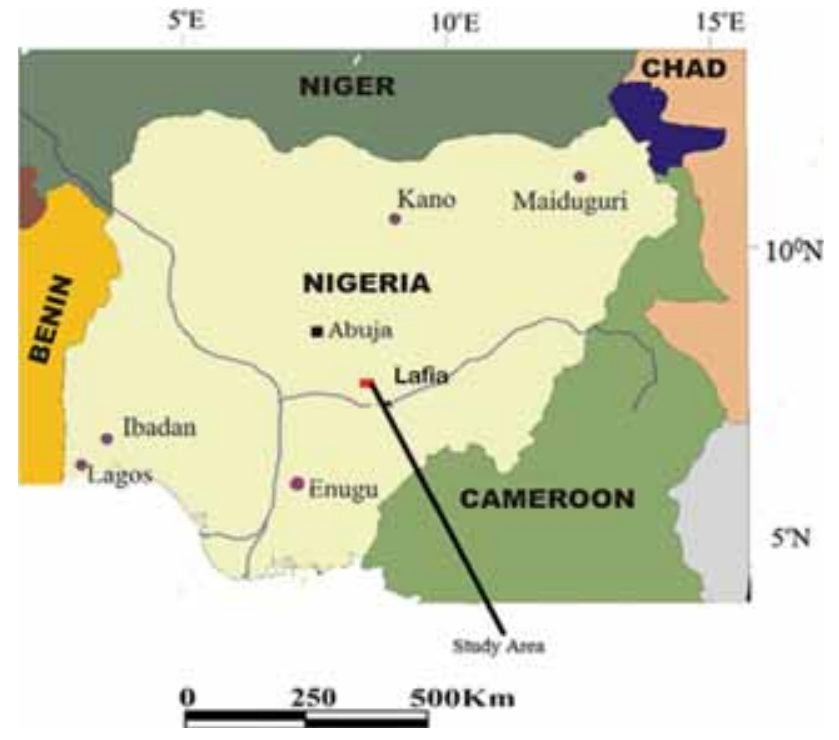

Figure 1. Map of Nigeria showing the location of the study area.

and claystones. The type locality is in and around Lafia town (Offodile 1976b) and outcrops along the banks of River Amba on the Lafia-Doma road. The formation is fine to coarse grained, friable and feldspathic. It ranges in thickness from about 10 to $150 \mathrm{~m}$ in the Lafia area and much thicker towards the south-west of the town. The formation thins out to the north, around Shabu (figure 2).

\subsection{Hydrogeology of the study area}

The study of the hydrogeology of the Lafia formation was to a very good extent pioneered by Offodile (1976a) who made a brief survey of the water resources of the area in light of its importance to the development of the region. A highlight of some hydrogeological characteristics of the aquifers of Lafia formation using drilled logs and water analyses of some selected wells in the area was made.

The Lafia formation comprises mainly fine to coarse grained sandstones, which are highly porous and permeable. The formation is highly permeable and gives rise to several springs (or marshy areas) called fadama at its contact with the less permeable underlying Awgu formation (Musa 2015).

\section{Materials and methods}

Thirty groundwater samples were collected from the discharge points of daily abstracted hand-dug wells and boreholes in the month of April 2017. Sampling was done early in the morning before water abstraction commenced by the residents covering areas such as Gandu, Doma, Yelwa Doma, Major Musa, Shabu, Mada and Assakio (figure 3), to characterise and evaluate its quality for drinking and agricultural purposes. The study area was gridded into four quadrants to have an even distribution of samples. Seven samples were collected from each quadrant while two samples were collected from the municipal centre at an arbitrary distance due to its high human activities. At every sample location, two water samples were collected for the detection of anions and cations. The samples were filtered in situ through a $0.45 \mu \mathrm{m}$ membrane filter, collected in labelled 125 $\mathrm{ml}$ bottles and kept under cold condition. Samples for cation analytes were acidified to a $\mathrm{pH}$ less than 2 with nitric acid in water solution at $0.15 \%$ concentration by weight. EC, temperature $\left(T^{\circ}\right)$ and hydrogen ion concentration $(\mathrm{pH})$ were measured in situ. A SOLINT temperature, level and conductivity (TLC) metre was used in measuring EC and $T^{\circ}$ by lowering it into a well. At the point of contact with water, the temperature and EC of the water is displayed and read from the digital screen of the metre. The $\mathrm{pH}$ metre was used in measuring $\mathrm{pH}$ while the evaporation technique using gravimetric analysis was used to determine total dissolved solids (TDS) (figure 4).

Atomic absorption spectrometry was used for the determination of $\mathrm{Ca}^{2+}, \mathrm{Fe}^{2+}$ and $\mathrm{Pb}^{2+}$ concentrations while a UV spectrophotometer was used in determining the concentration of $\mathrm{NO}_{3}^{-}$. The concentrations of $\mathrm{Na}^{+}$and $\mathrm{K}^{+}$were determined using flame analysis while titrimetric and colorimetric methods were used in determining the concentrations of $\mathrm{Cl}^{-}$and $\mathrm{HCO}_{3}^{-}$and $\mathrm{SO}_{4}^{2-}$, respectively. The results of anion and cation analytes were evaluated to calculate the WQI, hence the quality of the water for drinking was deduced. WQI was calculated according to Ramakrishnaiah et al. (2009), Reza and Singh (2010), Gebrehiwot et al. (2011) and Ishaku et al. (2012).

Based on the WQI value, groundwater are classified as excellent water, good water, permissible water, poor water, very poor water or water unsuitable for drinking purposes. Piper (1944) trilinear diagrams and Stiff pattern diagrams were used to characterize groundwater into different facies or types. The hardness of the water was evaluated in accordance with Todd and Mays (2005), to determine the potability of the water. 


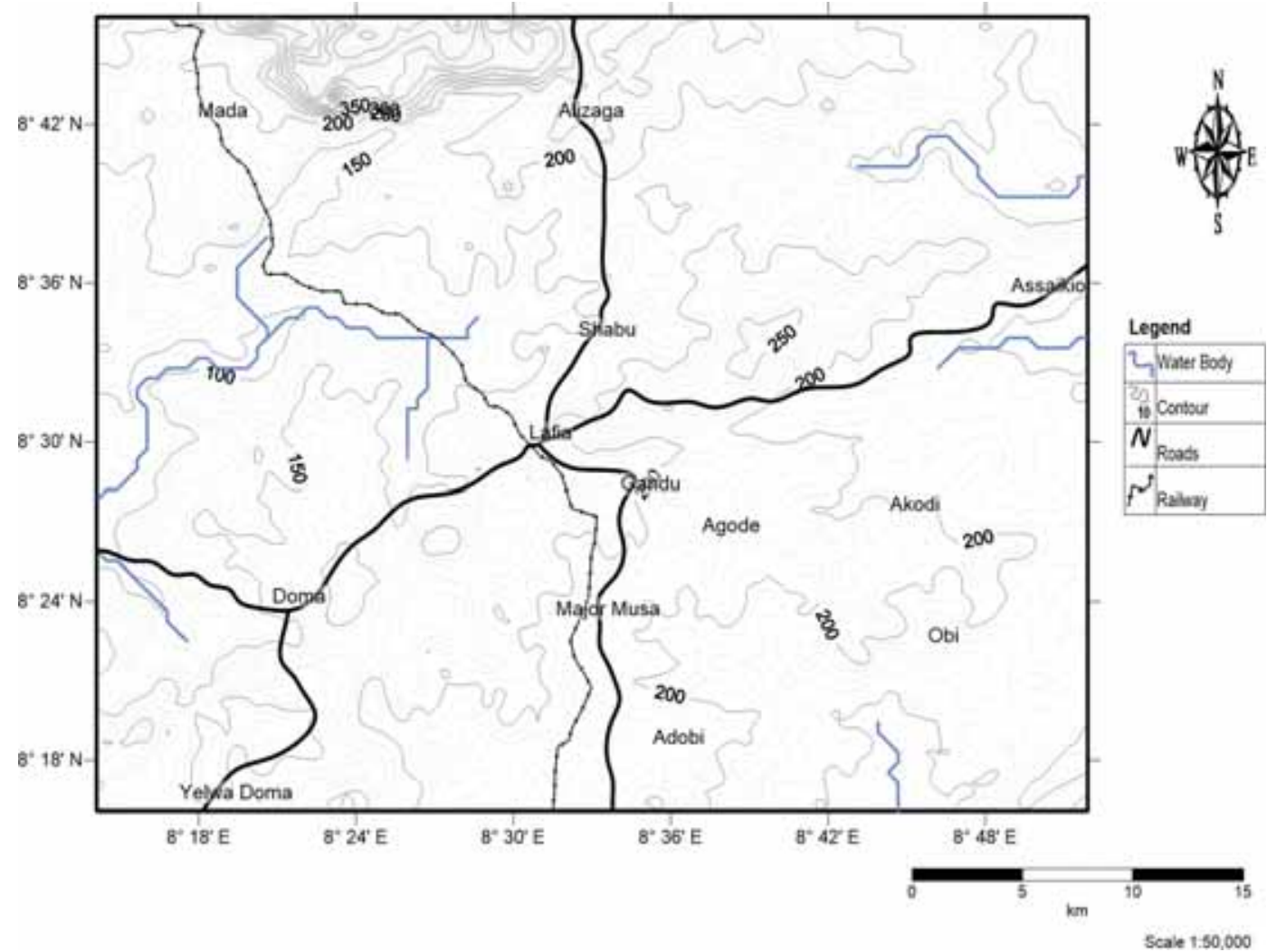

Figure 2. Topographic map of the study area.

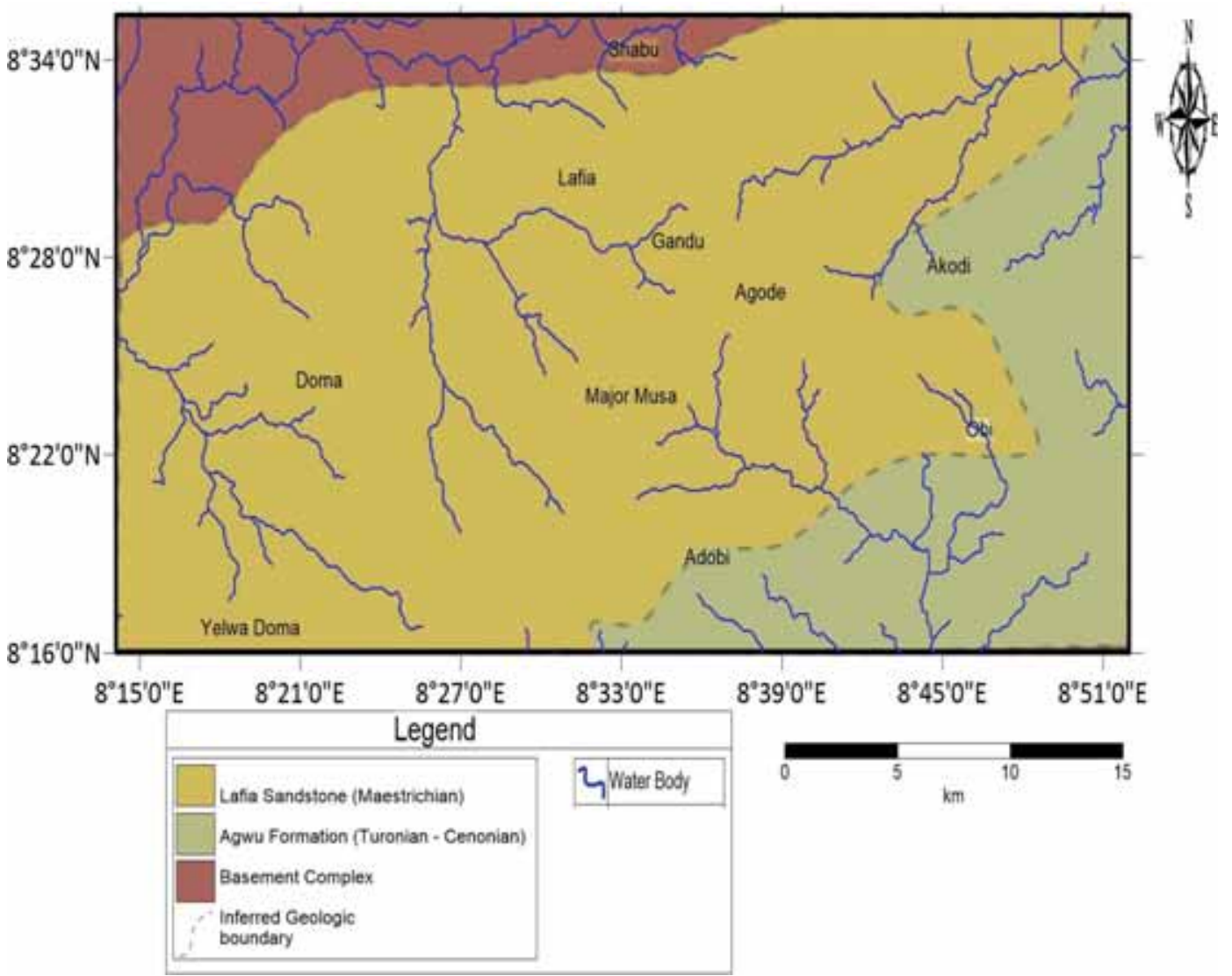

Figure 3. Geological map of the study area. 
WQI CHART

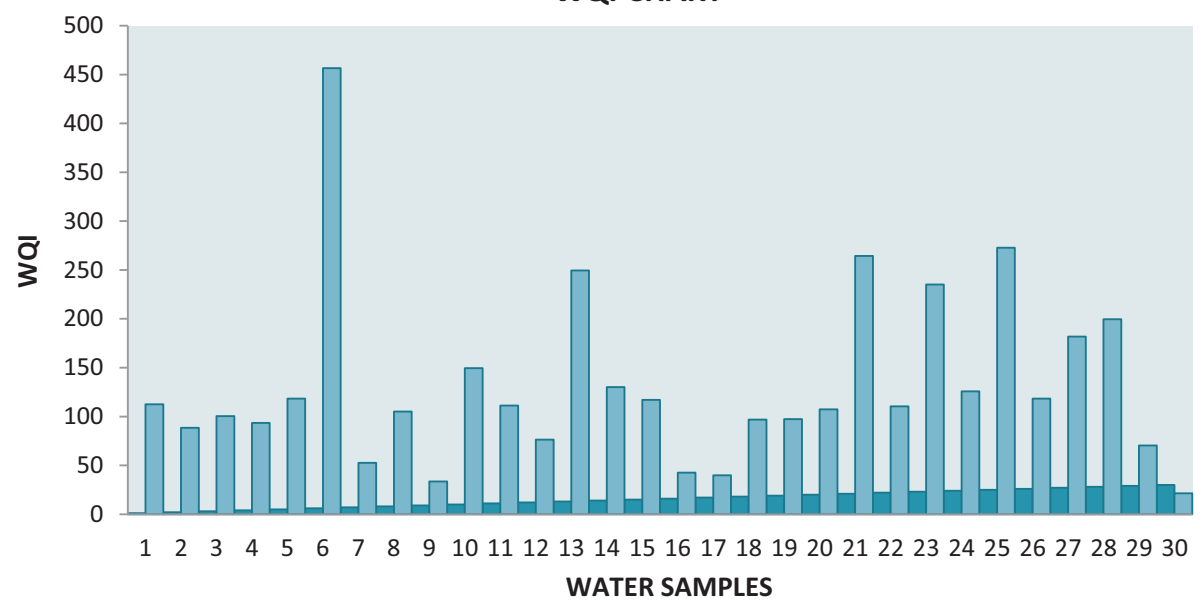

Figure 4. Graphical representation of WQI.

Table 1. Summary of physio-chemical parameters.

\begin{tabular}{|c|c|c|c|c|c|c|c|c|c|c|c|c|c|c|}
\hline Sample & $\mathrm{pH}$ & $\mathrm{EC}(\mu \mathrm{S} / \mathrm{cm})$ & TDS & $\% \mathrm{NO}_{3}^{-}$ & $\mathrm{PO}_{3}$ & $\mathrm{~K}^{+}$ & $\mathrm{SO}_{4}^{2-}$ & $\mathrm{HCO}_{3}^{-}$ & $\mathrm{Cl}^{-}$ & $\mathrm{Ca}^{2+}$ & $\mathrm{Mg}^{2+}$ & $\mathrm{Fe}^{2+}$ & $\mathrm{Pb}^{2+}$ & $\mathrm{Na}^{+}$ \\
\hline 1 & 6.6 & 759 & 86.2 & 2.49 & 0.17 & 0.2 & 0 & 85.4 & 0.2 & 0.221 & 0.063 & 1.538 & 0.088 & 0.119 \\
\hline 2 & 5.8 & 275 & 98.4 & 1.25 & 0.24 & 0.14 & 0 & 97.6 & 0.3 & 0.251 & 0.066 & 1.682 & 0.068 & 0.043 \\
\hline 3 & 5.6 & 479 & 111.5 & 4.37 & 0.28 & 0.24 & 0.26 & 109.8 & 0.2 & 0.331 & 0.082 & 1.953 & 0.074 & 0.621 \\
\hline 4 & 5.3 & 376 & 49.6 & 5.21 & 0.56 & 0.11 & 0 & 48.8 & 0.4 & 0.178 & 0.053 & 2.999 & 0.057 & 0.046 \\
\hline 5 & 5.1 & 320 & 136.9 & 2.18 & 0.57 & 0.09 & 0 & 134.2 & 0 & 0.114 & 0.033 & 2.502 & 0.092 & 2.511 \\
\hline 6 & 5.5 & 571 & 37.1 & 1.64 & 0.28 & 0.08 & 0 & 36.6 & 0.1 & 0.222 & 0.055 & 2.434 & 0.497 & 0.067 \\
\hline 7 & 5.4 & 110 & 85.9 & 1.23 & 0.19 & 0.1 & 0 & 85.4 & 0.19 & 0.116 & 0.032 & 2.825 & 0.015 & 0.023 \\
\hline 8 & 5.5 & 675 & 46.6 & 5.41 & 0.19 & 0.15 & 0.12 & 36.6 & 0.1 & 0.325 & 0.081 & 2.262 & 0.074 & 9.23 \\
\hline 9 & 6.3 & 167 & 98.2 & 2.49 & 0.1 & 0.08 & 0 & 97.6 & 0.2 & 0.266 & 0.066 & 1.942 & 0 & 0.014 \\
\hline 10 & 5.4 & 438 & 86.5 & 3.48 & 0.23 & 0.07 & 0 & 85.4 & 0.1 & 0.222 & 0.076 & 2.921 & 0.123 & 0.651 \\
\hline 11 & 5.8 & 244 & 134.8 & 1.76 & 0.28 & 0.1 & 0 & 134.2 & 0.09 & 0.267 & 0.089 & 2.363 & 0.086 & 0.004 \\
\hline 12 & 5.6 & 230 & 98.9 & 1.67 & 0.18 & 0.21 & 0.14 & 97.6 & 0 & 0.716 & 0.225 & 1.958 & 0.051 & 0.003 \\
\hline 13 & 5.4 & 149 & 73.8 & 2.49 & 0.27 & 0.02 & 0 & 73.2 & 0.29 & 0.216 & 0.072 & 2.081 & 0.26 & 0.014 \\
\hline 14 & 6.3 & 1396 & 50.5 & 2.18 & 0.48 & 0.15 & 0 & 48.8 & 0.79 & 0.21 & 0.076 & 2.194 & 0.09 & 0.462 \\
\hline 15 & 6.1 & 780 & 67.1 & 5.21 & 0.2 & 0.1 & 0 & 61 & 0.19 & 0.42 & 0.236 & 2.555 & 0.081 & 5.14 \\
\hline 16 & 5.9 & 435 & 49.6 & 4.62 & 0.23 & 0.13 & 0.01 & 48.8 & 0.1 & 0.116 & 0.053 & 2.527 & 0 & 0.341 \\
\hline 17 & 7.3 & 615 & 3.4 & 4.96 & 0.19 & 0.25 & 0.18 & 0 & 0 & 0.303 & 0.156 & 1.942 & 0 & 2.56 \\
\hline 18 & 5.7 & 248 & 122.7 & 3.98 & 0.54 & 0.1 & 0 & 122 & 0.1 & 0.31 & 0.134 & 1.779 & 0.076 & 0.094 \\
\hline 19 & 5.9 & 134 & 73.7 & 3.26 & 0.48 & 0.08 & 0 & 73.2 & 0.19 & 0.148 & 0.032 & 2.062 & 0.077 & 0 \\
\hline 20 & 5.8 & 264 & 62 & 4.46 & 0.12 & 0.09 & 0 & 61 & 0 & 0.239 & 0.043 & 2.925 & 0.076 & 0.624 \\
\hline 21 & 5.5 & 566 & 37.9 & 4.3 & 0.19 & 0.42 & 0.54 & 36.6 & 0.1 & 0.218 & 0.028 & 1.336 & 0.092 & 0 \\
\hline 22 & 5.5 & 211 & 49.3 & 2.7 & 0.44 & 0.11 & 0 & 48.8 & 0.11 & 0.113 & 0.041 & 1.313 & 0.077 & 0.084 \\
\hline 23 & 5.4 & 665 & 62 & 1.69 & 0.1 & 0.24 & 0.18 & 61 & 0.1 & 0.336 & 0.064 & 2.961 & 0.222 & 0.046 \\
\hline 24 & 6.3 & 198 & 98.7 & 3.23 & 0.19 & 0.04 & 0 & 97.6 & 0 & 0.406 & 0.624 & 2.74 & 0.1 & 0 \\
\hline 25 & 5.4 & 452 & 25.6 & 3.23 & 0.17 & 0.13 & 0.07 & 24.4 & 0 & 0.403 & 0.599 & 1.794 & 0.287 & 0 \\
\hline 26 & 5.3 & 249 & 74.2 & 5.01 & 0.27 & 0.1 & 0.02 & 73.2 & 0.1 & 0.301 & 0.021 & 1.844 & 0.103 & 0.481 \\
\hline 27 & 6.3 & 1396 & 37.7 & 4.33 & 0.18 & 0.08 & 0.01 & 36.6 & 0.11 & 0.361 & 0.364 & 1.873 & 0.156 & 0.214 \\
\hline 28 & 6.1 & 780 & 86.4 & 2.06 & 0.25 & 0.1 & 0.07 & 85.4 & 0.11 & 0.618 & 0.082 & 1.057 & 0.174 & 0 \\
\hline 29 & 5.8 & 432 & 74.6 & 2.75 & 0.47 & 0.43 & 0.54 & 73.2 & 0.09 & 0.229 & 0.077 & 2.048 & 0.039 & 0 \\
\hline 30 & 7.1 & 616 & 98.9 & 0.97 & 0.13 & 0.1 & 0.02 & 97.6 & 0.79 & 0.264 & 0.034 & & 0.024 & 0.14 \\
\hline
\end{tabular}

Secondary parameters such as the percentage of sodium (Na\%), SAR and $\mathrm{MH}$ were computed using mathematical equations (1)-(3) according to Richard (1954), Szabolcs and Darab (1964), Raghunath (1987), Todd and Mays (2005), Sadashivaiah et al. (2008) and Hagras (2013), 
respectively. These secondary parameters and the waters EC were used in evaluating the groundwater of the study area for irrigation purposes:

$$
\begin{aligned}
\mathrm{Na} \% & =\frac{\left(\mathrm{Na}^{+}+\mathrm{K}\right) \times 100}{\mathrm{Ca}+\mathrm{Mg}^{2+}+\mathrm{Na}^{+}+\mathrm{K}^{+}}, \\
\mathrm{SAR} & =\frac{\mathrm{Na}^{+}}{\sqrt{\frac{\mathrm{Ca}^{+}+\mathrm{Mg}^{+}}{2}}}, \\
\mathrm{MH} & =\frac{\mathrm{Mg}^{2+} X 100}{\mathrm{Ca}^{2+}+\mathrm{Mg}^{2+}} .
\end{aligned}
$$

\section{Results and discussions}

\subsection{Hydrochemistry}

From the physiochemical analysis of the groundwater samples, the order of dominance of the anions is $\mathrm{HCO}_{3}^{-}>\mathrm{NO}_{3}^{-}>\mathrm{Cl}^{-}>\mathrm{PO}_{3}^{-}>\mathrm{SO}_{4}^{2-}$ and $\mathrm{Fe}^{2+}>\mathrm{Na}^{+}>\mathrm{Ca}^{2+}>\mathrm{Mg}^{2+}>\mathrm{Pb}^{2+}>$ $\mathrm{K}^{+}$for the cations (table 1$)$. Bicarbonate $\left(\mathrm{HCO}_{3}^{-}\right)$

Table 2. Summary of the statistical analysis of the physiochemical parameters.

\begin{tabular}{lcccc}
\hline & & & & $\begin{array}{l}\text { WHO } \\
(2011)\end{array}$ \\
Parameters & Mean & Max & Min & standard \\
\hline $\mathrm{pH}$ & 5.85625 & 7.3 & 5.1 & $6.2-8.5$ \\
$\mathrm{EC}$ & 491.75 & 1396 & 110 & 500 \\
$\mathrm{TDS}$ & 73.71875 & 136.9 & 3.4 & 600 \\
$\mathrm{NO}_{3}^{-}$ & 3.155938 & 5.41 & 0.97 & 200 \\
$\mathrm{PO}_{3}^{-}$ & 0.27625 & 0.57 & 0.1 & 200 \\
$\mathrm{~K}^{+}$ & 0.146563 & 0.43 & 0.02 & 75 \\
$\mathrm{SO}_{4}^{2-}$ & 0.084375 & 0.54 & 0.01 & 50 \\
$\mathrm{HCO}_{3}^{-}$ & 72.05625 & 134.2 & 24.4 & 0.01 \\
$\mathrm{Cl}^{-}$ & 0.1825 & 0.79 & 0.1 & 250 \\
$\mathrm{Ca}^{2+}$ & 0.289656 & 0.716 & 0.113 & 250 \\
$\mathrm{Mg}^{2+}$ & 0.134438 & 0.624 & 0.021 & 50 \\
$\mathrm{Fe}^{2+}$ & 3.20271 & 16.336 & 1.538 & 0.1 \\
$\mathrm{~Pb}^{2+}$ & 0.11425 & 0.497 & 0.1 & 10 \\
$\mathrm{Na}^{+}$ & 1.023813 & 9.23 & 0.1 & 500 \\
\hline
\end{tabular}

Table 3. Classification of water type (Vasanthavigar et al. 2010).

\begin{tabular}{ll}
\hline Range & \multicolumn{1}{c}{ Water type } \\
\hline$<50$ & Excellent water \\
$50-100.1$ & Good water \\
$100-200.1$ & Poor water \\
$200-300.1$ & Very poor water \\
$>300$ & Water unsuitable for drinking purposes \\
\hline
\end{tabular}

is the most dominant anion having a concentration range of $36.6-134.2 \mathrm{mg} / \mathrm{l}$ and an average value of $72.06 \mathrm{mg} / \mathrm{l}$. Sewage effluents emanating from pit latrines are the major source of bicarbonate, especially around Assakio, Doma, Gandu and Yelwa Doma areas and the dissolution of carbonate rocks such as limestone. Sulphate has the least concentration ranging between 0.01 and $0.54 \mathrm{mg} / \mathrm{l}$ with a mean value of $0.084 \mathrm{mg} / \mathrm{l}$ and it is associated with the dissolution of gypsum and anthropogenic activities. The $\mathrm{Fe}^{3+}$ has the highest concentration and ranges from 1.54 to $16.33 \mathrm{mg} / \mathrm{l}$, with an average of $3.20 \mathrm{mg} / \mathrm{l}$, which is above the WHO recommended limit $(0.1 \mathrm{mg} / \mathrm{l})$ for drinking water. The high concentration of $\mathrm{Fe}^{3+}$ in the groundwater of the study area is attributable to the geological formation (ferruginised sandstones and lateritic soil) which are rich in $\mathrm{Fe}^{3+}$ as revealed by Musa

Table 4. Water quality classification.

\begin{tabular}{ccl}
\hline Samples & WQI & \multicolumn{1}{c}{ Description } \\
\hline 1 & 112.4502 & Poor water \\
2 & 88.47689 & Good water \\
3 & 100.4163 & Good water \\
4 & 93.48218 & Good water \\
5 & 118.334 & Poor water \\
6 & 456.546 & Water unsuitable \\
& & for drinking \\
& & purposes \\
7 & 52.64959 & Good water \\
8 & 105.1239 & Poor water \\
9 & 33.48885 & Excellent water \\
10 & 149.5036 & Poor water \\
11 & 111.2053 & Poor water \\
12 & 76.30788 & Good water \\
13 & 249.5194 & Very poor water \\
14 & 130.2028 & Poor water \\
15 & 116.9684 & Poor water \\
16 & 42.57073 & Excellent water \\
17 & 39.79386 & Excellent water \\
18 & 96.83334 & Good water \\
19 & 97.36963 & Good water \\
20 & 107.3812 & Poor water \\
21 & 264.4366 & Very poor water \\
22 & 110.4159 & Poor water \\
23 & 235.1214 & Very poor water \\
24 & 125.7777 & Poor water \\
25 & 272.77 & Very poor water \\
26 & 118.2779 & poor water \\
27 & 181.7663 & Poor water \\
28 & 199.6623 & Poor water \\
29 & 70.37273 & Good water \\
30 & 21.4125 & Excellent water \\
\hline & &
\end{tabular}


(2015). The high concentration of $\mathrm{Na}^{+}$compared to $\mathrm{Ca}^{2+}$ (mean values of 1.02 and $0.28 \mathrm{mg} / \mathrm{l}$, respectively) denotes the effect of ion exchange between them (Kumar 2013). Leaching of clay minerals is one the major sources of the cations.

\subsection{Water quality for drinking purposes}

Results of the physiochemical parameters are summarized in table 1 and were correlated with the WHO (2011) standards to evaluate and characterise groundwater for drinking. The $\mathrm{pH}$ of the groundwater (table 2) ranges from 5.1 to 7.3 with a mean value of 5.86 (weakly acidic to slightly alkaline). Low $\mathrm{pH}$ is caused by the precipitation of iron in stored water sampled before testing, while high $\mathrm{pH}$ results from the presence of bicarbonates, carbonates and hydroxides of calcium. The EC has an average of $491.75 \mu \mathrm{S} / \mathrm{cm}$ with $36.67 \%$ of the water samples having an EC range of 566-1396 $\mu \mathrm{S} / \mathrm{cm}$ above the WHO (2011) limit, while $63.33 \%$ of the samples with an EC range of $110-479 \mu \mathrm{S} / \mathrm{cm}$ are within the WHO (2011) limit. TDS is the measure of the inorganic pollution load of a water system which shows that the groundwater in the study area can be classified as freshwater according to Carroll (1962) classification. It has a peak and the lowest values of 136.9 and $3.4 \mathrm{mg} / \mathrm{l}$, respectively, with a mean value of $73.72 \mathrm{mg} / \mathrm{l}$. High TDS may cause a laxative or constipation effect (APHA 1995). The $\mathrm{pH}$ values are within the range reported by Musa (2015) while the EC and TDS values contradict those reported by the author for Lafia (who limits his studies to only hand-dug wells; table 3 ). The ground WQI ranges from 21.41 to 456.55 with a mean value of 139.27 (table 4). About 13.33\% of the water samples are classified as excellent water with a WQI range of $21.41-42.57 ; 26.67 \%$ as good water (WQI range $52-100$ ); $43.34 \%$ as poor water (WQI range 105-199); $13.33 \%$ as very poor water (WQI range 235-272) and 3.33\% (sample 6 ) as water unsuitable for drinking purposes. The southern part of the study area (Yelwa Doma, Major Musa and Adobi) is dominated by good water. Poor water and very poor water are concentrated in the central part (Lafia and Doma) areas, even though some locations within the central parts such as Gandu and Agode contained excellent and good water. The poor to very poor water in the central part can be attributed to industrial waste such as e-waste, indiscriminate refuse dumps, to sewage effluent from pit latrines brought about by the dense population compared to the southern or northern parts with less population.

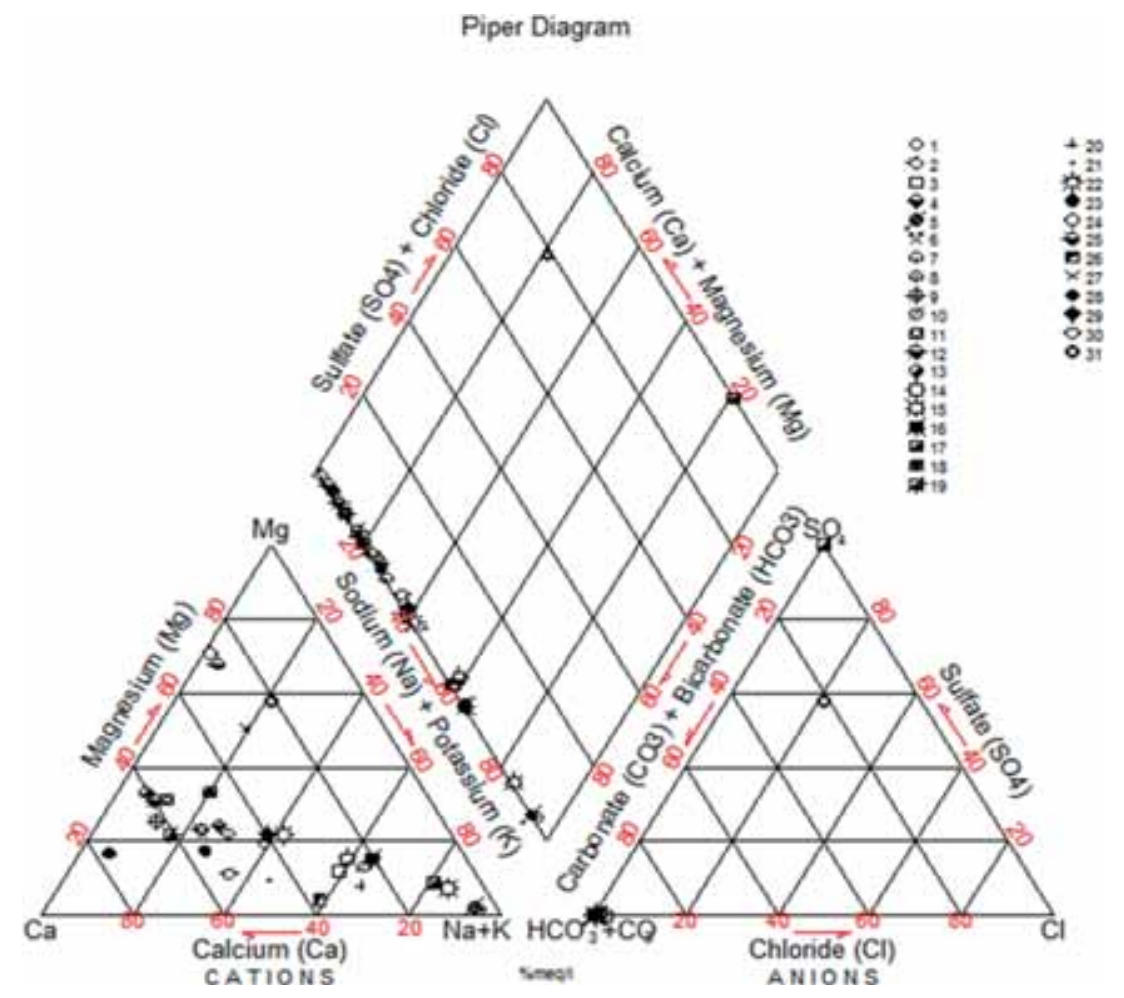

Figure 5. Piper trilinear diagram of the study area. 


\subsection{Water type}

Groundwater in the study area was characterized using Piper trilinear and Stiff diagrams (figures 5 and 6 , respectively). Three water types were deduced: the $\mathrm{Ca}^{2+}+\mathrm{Mg}^{2+}$ water type known for temporary hardness; the $\mathrm{Ca}^{2+}+\mathrm{Na}^{+}+\mathrm{K}^{+}$water type and the $\mathrm{HCO}_{3}^{-}+\mathrm{CO}_{3}^{-}$water type. The $\mathrm{Ca}^{2+}$ $+\mathrm{Mg}^{2+}$ and $\mathrm{Ca}^{2+}+\mathrm{Na}^{+}+\mathrm{K}^{+}$water types are the dominant types. The trend of the $\mathrm{Ca}^{2+}+$ $\mathrm{Mg}^{2+}$ water type in a straight line on the Piper diagram (figure 6) is an indication of a solution or precipitation. The source of the $\mathrm{HCO}_{3}^{-}+\mathrm{CO}_{3}^{-}$ water type is rainfall mixed with atmospheric carbon dioxide, usually low in calcium and magnesium and is said to be juvenile water (Akpah et al. 2017).

The Stiff pattern diagrams showed similar patterns for all samples with the exception of samples 8, 15 and 17. Water with similar qualities tends to plot together as a group while the size of the pattern is approximately equal to the ionic content. The similarity in pattern is an indication
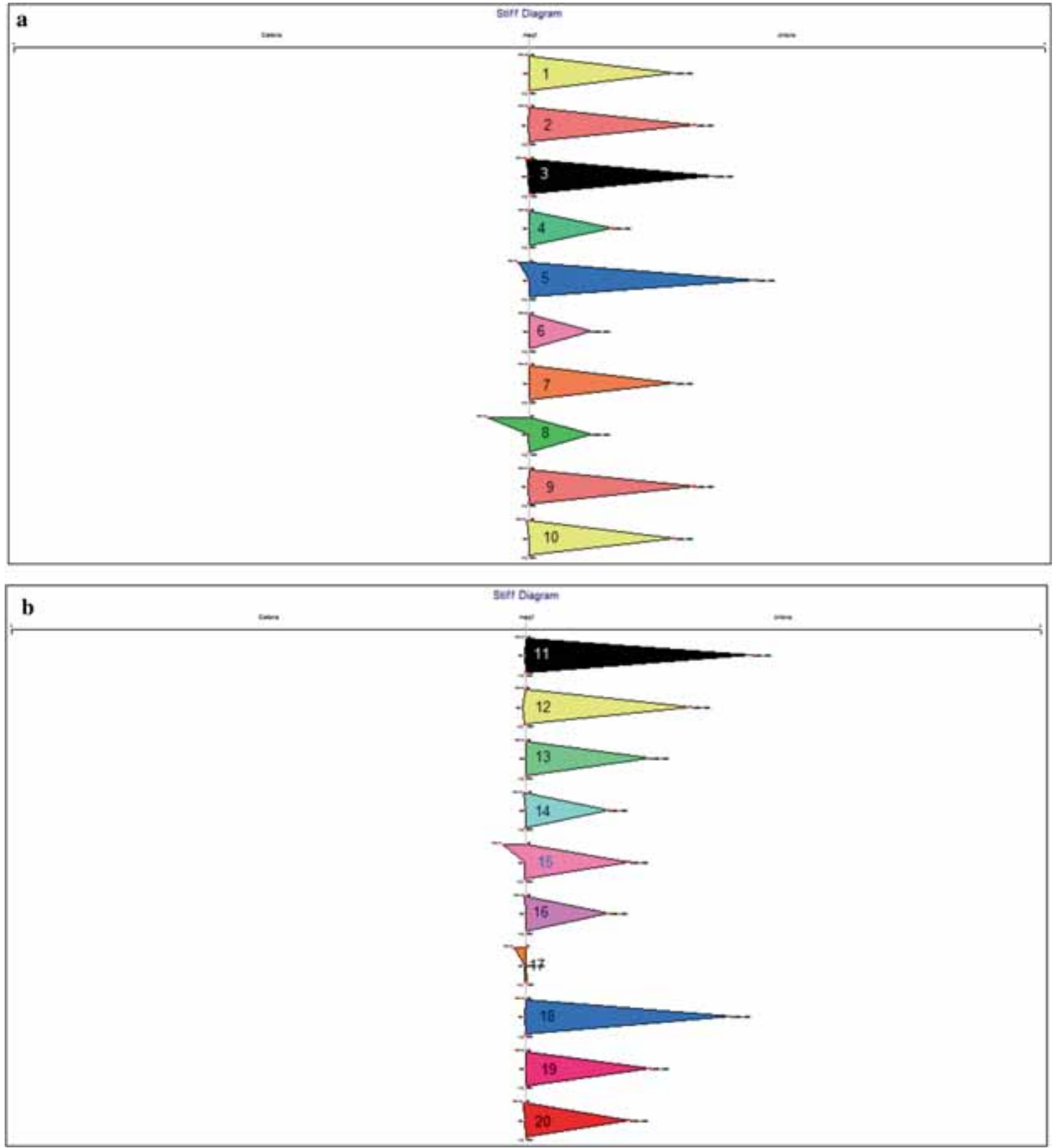

Figure 6. (a-c) Stiff (1951) patterns of the study area. 


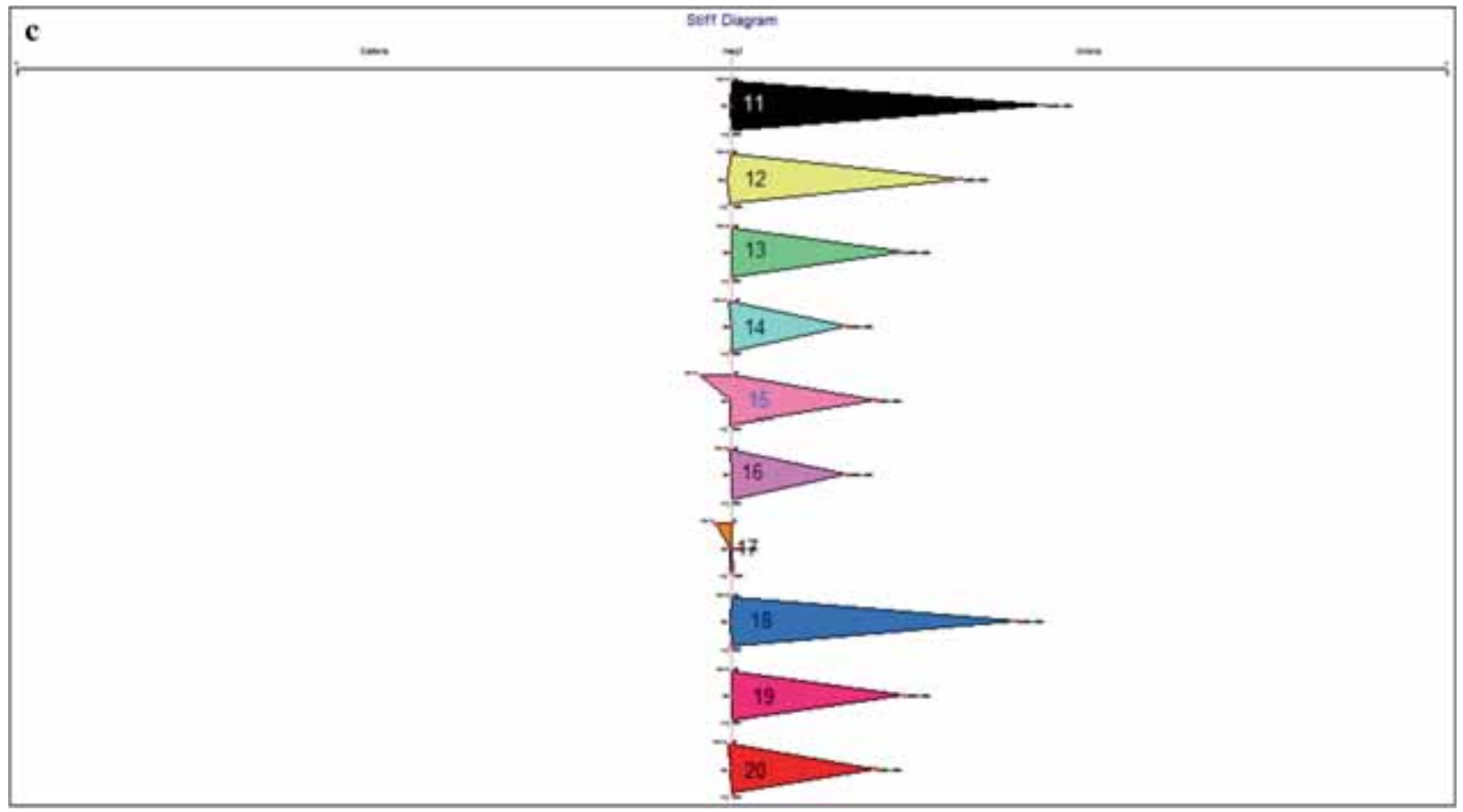

Figure 6. continued

that the waters are of the same source with little variation in TDS due to the differences in temperatures which causes dissolution, ion exchange capacity and adsorption (Ngabirano et al. 2016).

\subsection{Hardness}

The total hardness $\left(H_{T}\right)$ of the water samples was calculated according to Todd and Mays (2005), using the cations $\mathrm{Ca}^{2+}$ and $\mathrm{Mg}^{2+}$ which controls groundwater hardness. The $H_{T}$, ranges from 0.42 to 3.57 , with a mean value of 1.25 . Groundwater in the study area is classified as very soft water (Linsley et al. 1992) and hence poses no health risk that may arise from the excessive consumption of calcium or magnesium.

\subsection{Water quality for irrigation}

Chemical composition and usage conditions are the determinants of water quality for irrigation (Hussein et al. 2010). In this research, the EC, \% Na, the SAR and MH were used to evaluate groundwater in the study area for irrigation. The EC ranges from 110 to 1396 , having a mean value of 491 . Based on the EC classification of water for irrigation, $33.33 \%$ of the water samples are considered excellent, $60 \%$ as good while $6.67 \%$ are permissible. $\% \mathrm{Na}$ in water samples varied between 3.738 and 95.851 , with an average value of 48.31 (table 5 ). It showed that
$23.33 \%$ of water samples are good, permissible and doubtful, respectively, while $16.67 \%$ are excellent and $13.34 \%$ are unsuitable for irrigation. Low $\mathrm{Na}^{+}$water can be used for irrigation on all soils with minimal danger of harmful exchangeable $\mathrm{Na}^{+}$ developing (Singh et al. 2009), while on the other hand, high sodium water in most soils will require special soil management, such as good drainage, high leaching and organic matter as it produces harmful exchangeable sodium (Akpah et al. 2017). High $\mathrm{Na} \%$ in water will result in the replacement of $\mathrm{Mg}^{2+}$ and $\mathrm{Ca}^{2+}$ by $\mathrm{Na}^{+}$which impedes soil permeability, reduces soil drainage, affects soil structure and aeration and therefore, affects plant growth (Singh et al. 2008, 2009; Akpah et al. 2017). SAR ranges between 0.004 and 20.47 with a mean value of 1.87. Based on SAR, $96.67 \%$ and $3.33 \%$ of the groundwater are classified as excellent and doubtful waters, respectively. The low SAR of the water samples implies that the water will make the soil soft, loose and pervious with little sodium accumulation in the soil, as high SAR is responsible for compact, hard and impervious soils (George 1983; Akpah et al. 2017). Plants in the study area will have low susceptibility to sodium hazard or sodicity (Uzoije et al. 2015) as the soil's physical conditions will be suitable for good plant germination. The proportion of sodium to other cations is one of the most useful criteria for determining the quality of water for irrigation. The $\mathrm{MH}$ of 
Table 5. Description of groundwater for irrigation purposes based on EC and \%Na (after Raghunath 1987; Sadashivaiah et al. 2008; Hagras 2013) and SAR (after Richard 1954; Todd and Mays 2005).

\begin{tabular}{lcccccc}
\hline Description & EC & \% of sample & Na $\%$ & $\%$ of sample & SAR & $\%$ of sample \\
\hline Excellent & $<250$ & 33.33 & $<20$ & 16.67 & $<10$ & $10-18$ \\
Good & $250-750$ & 60 & $20-40$ & 23.33 & -67 \\
Permissible & $750-2000$ & 6.67 & $40-60$ & $60-80$ & 23.33 & - \\
Doubtful & $2000-3000$ & - & $>8-0$ & 13.34 & 3.33 \\
Unsuitable & $>3000$ & - & & $>26$ & - \\
\hline
\end{tabular}

groundwater ranges from $6.52 \%$ to $60.58 \%$, with an average value of $25.83 \%$. $\mathrm{MH}>50$ is considered unsuitable or harmful for irrigation (Szabolcs and Darab 1964; Singh et al. 2009; Brindha et al. 2014; Akpah et al. 2017). Only $6.6 \%$ of the water samples fall within this category, while $93.4 \%$ with $\mathrm{MH}<50$ are considered suitable for irrigation (Al-Tabbal and Al-Zboon 2012).

\section{Conclusion}

Groundwater assessment in Lafia and environs was carried out to determine its suitability for various purposes. The hydrochemistry revealed the anions and cations in order of dominance as $\mathrm{HCO}_{3^{-}}>$ $\mathrm{NO}_{3-}>\mathrm{Cl}^{-}>\mathrm{PO}_{3^{-}}>\mathrm{SO}_{4^{2-}}$ and $\mathrm{Fe}^{3+}>$ $\mathrm{Na}^{+}>\mathrm{Ca}^{2+}>\mathrm{Mg}^{2+}>\mathrm{Pb}^{2+}>\mathrm{K}^{+}$, respectively. All parameters fall below the WHO recommended limit for drinking water except for $\mathrm{Fe}^{3+}$, which was as high as $16.53 \mathrm{mg} / \mathrm{l}$. The high concentration of $\mathrm{Fe}^{3+}$ in the groundwater of the study area can be attributed to the oxidation of $\mathrm{Fe}^{2+}$ present in ferruginised sandstones and lateritic soil.

WQI showed that $13.33 \%$ of groundwater in the study area can be classified as excellent water, $30 \%$ as good water, $40 \%$ as poor water, $13.33 \%$ as very poor water and $3.33 \%$ as water unsuitable for drinking purposes. Groundwater in the study area was characterised into three types using Piper's (1944) trilinear diagram, with type I as the $\mathrm{Ca}^{2+}+\mathrm{Mg}^{2+}$ water type, Type II as the $\mathrm{Ca}^{2+}$ $+\mathrm{Na}^{+}+\mathrm{K}^{+}$water type and Type III as the $\mathrm{HCO}_{3}^{-}+\mathrm{CO}_{3}^{-}$water type. The Types I and II are the dominant water types. Type I water is known for temporary hardness, while rainfall mixed with atmospheric carbon dioxide is believed to be the source of the $\mathrm{HCO}_{3}^{-}+\mathrm{CO}_{3}^{-}$type. The Stiff pattern showed similar patterns for all samples with the exception of samples 8,15 and 17 , which is an indication that the water are of the same source, with little difference in the TDS in the groundwater of the study area.
Based on the EC, \% Na, SAR and the $\mathrm{MH}$ evaluated, the groundwater in the study area generally ranges from permissible to excellent water for irrigation.

\section{Acknowledgements}

The first author is grateful to the Petroleum Technology Development Fund (PTDF) for the offer of scholarship to pursue a doctoral degree in hydrogeology.

\section{References}

Achohwora P 1986 Some hydrogeological aspects of the Lafia Coal Deposit, Plateau state; Unpublished Master's Thesis, Ahmadu Bello University, Zaria, pp. 1-37.

Akpah F A, Onwuka S O and Oha I A 2017 Hydrogeochemical investigation and characterization of shallow groundwater within Ankpa Town, North Central Nigeria; Int. J. Phys. Sci. 12(5), 60-73, https://doi.org/10.5897/ IJPS2016.4595

Aku I M 1983 Groundwater resources of the Lafia Water catchment area. Plateau state, Nigeria; Unpublished Master's Thesis, Ahmadu Bello University, Zaria, p. 3.

Al-Tabbal J A and Al-Zboon K K 2012 Suitability assessment of groundwater for irrigation and drinking purpose in the northern region of Jordan; J. Env. Sci. Technol. 5 274-290.

APHA (American Public Health Association) 1995 Standard methods for examination of water and waste water; American Public Health Association, American Water Works Association and Water Pollution Control Federation, Washington, DC, USA.

Binbol N L 2006 A climate of Nasarawa state; Report of Geographical Prospective on Nasarawa State, Department of Geography, Nasarawa State University.

Bocanegra E, Londono O M Q, Martinez D E and Romanelli A 2013 Quantification of the water balance and hydrogeological processes of groundwater-lake interactions in the Pampa Plain, Argentina; Environ. Earth Sci. $682347-$ 2357.

Bouderbala A, Remini B, SaaedHamoudi A and PulidoBosch A 2016 Assessment of groundwater vulnerability and quality in coastal aquifers: A case study (Tipaza, North Algeria); Arab. J. Geosci. 9181. 
Brindha K, NeenaVaman K V, Srinivasan K, Sathis B M and Elango L 2014 Identification of surface water-groundwater interaction by hydrogeochemical indicators and assessing its suitability for drinking and irrigation purposes in Chennai, south India; Appl. Water Sci. 4 159-174.

Carroll D 1962 Rainwater as a chemical agent of geologic processes: A review; U.S. Geological Survey Water Supply Paper 1535-G, 18p.

Cratchley C R and Jones G P 1965 An interpretation of the geology and gravity anomalies of the Benue valley Nigeria; Overseas Geol. Surv. Geophys. Paper 1 1-26.

Das S and Nag S K 2015 Deciphering groundwater quality for irrigation and domestic purposes - A case study in Suri I and II blocks, Birbhum District, West Bengal, India, India; J. Earth Syst. Sci. 124(5) 965-992, https://doi. org/10.1007/s12040-015-0583-8.

Ehirim C N, Ebeniro J O and Ogwu D A 2009 A geophysical and hydro-physiochemical study of the impact of a solid waste landfill (SWL) in Port Harcourt municipality, Nigeria; Pacific J. Sci. Technol. 10(2) 596-603.

Gebrehiwot A B, Tadesse N and Jigar E 2011 Application of water quality index to assess suitability of groundwater quality for drinking purposes in Hantebet watershed, Tigray, Northern Ethiopia; ISABB J. Food Agric. Sci. 1(1) 22-30.

George P R 1983 Agricultural water quality criteria, irrigation aspects; Resource Management Technical Report Number 30, Government of Western Austria, ISSN-07293135 .

Hagras M A 2013 Water quality assessment and hydrochemical characteristics of groundwater in Punjab, Pakistan; Int. J. Res. Rev. Appl. Sci. 16(2) 254-262.

Hussein G, Alquwaizany A and Al-Zarah A 2010 Guidelines for irrigation water quality and water management in the kingdom of Saudi Arabia: An overview; J. Appl. Sci. 10(2) 79-96.

Ishaku J M 2011 Assessment of groundwater quality index for Jimeta-Yola area, Northeastern Nigeria; J. Geol. Min. Res. 3(9) 219-231.

Ishaku J M, Ahmed A S and Abubakar M A 2012 Assessment of groundwater quality using water quality index and GIS in Jada, northeastern Nigeria; Int. Res. J. Geol. Min. 2(3) $54-61$.

Kumar P J S 2013 Interpretation of groundwater chemistry using Piper and Chadha's diagrams: A comparative study from Perambalur taluk; Elixir Geosci. 54 12208-12211.

Linsley R K, Franzini J B, Freyberg D L and Tchobanoglous G 1992 Water resources engineering, McGraw-Hill series on water resources and environmental engineering; McGraw-Hill, New York.

Michael A M 1990 Irrigation; Theory and practice; New Delhi: Vikas Publishing House Pvt. Ltd.

Musa M U 2015 Hydrogeology and groundwater quality of Lafia and its environs, sheet 231, Lafia, Nasarawa state, north central Nigeria; Unpublished Master's Thesis, Ahmadu Bello University, Zaria, pp. 57-89.

Ngabirano H, Byamugisha D and Ntambi E 2016 Effects of seasonal variations in physical parameters on quality of gravity flow water in Kyanamira Sub-County, Kabale District, Uganda; J. Water Resour. Prot. 8 1297-1309.
Offodile M E 1976a The geology of the middle Benue trough, Nigeria; Publication from The Palaeontological Institution of the University of Uppsala, Germany, pp. $41-167$.

Offodile M E 1976b A review of the geology of the cretaceous of the Benue Valley. In: Geology of Nigeria (ed) Kogbe CA, Elisabethan Publishing Co., Lagos, pp. 319-330.

Offodile M E 1983 The geology and tectonic of Awe brine fields; J. Afr. Earth Sci. 2(3) 191-202.

Offodile M E 2002 Groundwater study and development in Nigeria, Mecon Geology and Engineering Services Ltd. Jos, Nigeria.

Omonona O V, Onwuka O S and Okogbue C O 2014 Characterization of groundwater quality in three settlement areas of Enugu metropolis, Southeastern Nigeria, using multivariate analysis; Env. Monit. Assess. 186 651-664.

Onwuka O S, Uma K O and Ezeigbo H I 2004 Potability of shallow groundwater in Enugu town, Southeastern Nigeria; Glob. J. Env. Sci. 3(1) 33-39.

Onwuka O S, Omonona O V and Anika O C 2013 Hydrochemical characteristics and quality assessment of regolith aquifers in Enugu Metropolis, Southeastern Nigeria; Env. Earth Sci. 70 1135-1141.

Piper A M 1944 A graphic procedure in geochemical interpretation of water analyses; Trans. Am. Geophys. Union. 25 914-923.

Prasanna M V, Chidambaram S and Hameed A S et al. 2011 Hydrogeochemical analysis and evaluation of groundwater quality in the Gadilam river basin, Tamil Nadu, India; J. Earth Syst. Sci. 120 85-98, https://doi.org/10.1007/ s12040-011-0004-6.

Raghunath M H 1987 Groundwater; 2nd edn, Wiley Eastern Limited, New Delhi, pp. 344-369.

Ramakrishnaiah C R, Sadashvaiah C and Ranganna G 2009 Assessment of water quality Index for the groundwater in Tumkur Taluk, Karnataka state, India; E-J. Chem. 6(2) 523-530.

Rao G T, Rao V V S G and Ranganathan K 2013 Hydrogeochemistry and groundwater quality assessment of Ranipet industrial area, Tamil Nadu, India; J. Earth Syst. Sci. 122(3) 855-866, https://doi.org/10. 1007/s12040-013-0295-x

Reza R and Singh G 2010 Assessment of ground water quality status by using water quality Index method in Orissa, India; World Appl. Sci. J. 9(12) 1392-1397.

Richard L A 1954 Diagnosis and improvement of saline and alkali soils; United State Department of Agriculture Handbook, Government Printing Office, Washington, DC.

Sadashivaiah C, Ramakrishnaiah C R and Ranganna G 2008 Hydrochemical analysis and evaluation of groundwater quality in Tumkur Taluk Karnataka state, India; Int. J. Env. Res. Publ. Health 5(3) 158-164.

Singh A K, Mondal G C, Kumar S, Singh T B, Tewary B K and Sinha A 2008 Major ion chemistry, weathering processes and water quality assessment in upper catchment of Damodar river basin, India; Env. Geol. 54(4) 745-758.

Singh A K, Mondal G C, Tewary B K and Sinha A 2009 Major ion chemistry, solute acquisition processes and quality assessment of mine water in Damodar valley coalfields, India; In: Abstract of the mine water conference, Proceedings, ISBN Number 978- 0-9802623-5-3, produced 
by Document Transformation Technologies cc, Pretoria, South Africa, pp. 267-276.

Stiff H A 1951 The interpretation of chemical water analysis by means of patterns; J. Petrol. Technol. 3 15-17.

Szabolcs I and Darab C 1964 The influence of irrigation water of high sodium carbonate content of soils; Proc. Int. Congr. Trans. 2 803-812.

Tiwari T N and Mishra M A 1985 A preliminary assessment of water quality index of major Indian rivers; $J$. Env. Prot. 5 276-279.

Todd D K and Mays L M 2005 Groundwater hydrology, 3rd edn; Wiley, New York.

Uzoije A P, Uche C C, Uzo E and Raphael G 2015 Suitability assessment of shallow groundwater of a typical coastal aquifer for irrigation use: A water quality index model approach; IOSR J. Mech. Civil Eng. 12(6) 55-60.

Vasanthavigar M, Srinivasamoorthy K, Rajiv Gantha R, Vijayaraghavan K and Sarma V S 2010 Characterization and quality assessment of groundwater with special emphasis on irrigation utility: Thirumanimuttar subbasin, Tamil Nadu, India; Arab. Geosci. J. https://doi. org/10.1007/s12517-010-0190-6.

World Health Organisation (WHO) 2011 Standard permissible limit for physical and chemical parameters of water for drinking and domestic use. WHO, Geneva

Zaborski P M 1998 A review of the cretaceous system in Nigeria; Afr. Geosci. Rev. 5(4) 387.

Corresponding editor: ABhiJit MukherJeE 